\title{
WHY FAMILY FIRMS IN POLAND CHOOSE TO DIVERSIFY THEIR BANKING RELATIONSHIPS
}

This article deals with relationship banking as a multidimensional and relatively complicated set of interrelations between a company and cooperating banks. In this paper, relationship banking is understood as long and intensive partnerships between banks and family firms that exceed simple bundles of anonymous transactions. Relationship banking benefits, for both the bank (credit risk mitigation and cross-selling packages of services) and the borrower (access to credit, "one-stop" dealings and insurance against adversity), compel exclusivity. In this context, the paper aims to identify how family firms decide to cooperate with a given number of banks and why firms make decisions to have multiple bank relationships despite the obvious advantages of staying with one bank. Using multinomial logit models that describe a situation when the dependent variable is discretely selected from the set consisting of more than two categories, we analysed data of more than 390 Polish firms from interview-based questionnaires about the reasons for establishing relationships with two, three or more banks. We find that firms that identify themselves as family firms tend to have a second bank with which they have long worked. If the family is using one of the firm's banks for private affairs, they tend to use three or more banks. Manufacturing family firms tend to use three or more banks. Large family firms tend to establish relationships with more banks. Based on these findings, banks can build their relationships with family firms in a better way.

Keywords: banks, relationship banking, family firms

JEL Classifications: G21, G32, G34

DOI: $10.15611 /$ aoe.2019.2.03

\section{INTRODUCTION}

Firms in a developed market will typically need an array of banking services: money transfers, deposits, access to credit and many other specialized banking products. This article does not deal with the different types of banking products. Rather, the main focus is the nature of the relationships between firms and their banks. In servicing the business sector, most banks differentiate between three basic market segments: retail (firms

\footnotetext{
* Department of Banking, Maria Curie-Skłodowska University in Lublin.

** Institute of Finance, Department of Corporate Finance, Johannes Kepler University, Linz, Austria.
} 
that operate as private individuals or sole-proprietors rather than developed companies); commercial (firms running businesses that are more developed than retail and have a need for more sophisticated bank products and services) and large corporations. Because the provision of personal services of a dedicated bank officer is an expensive fixed cost, it is difficult to justify in the case of the smallest borrowers. Banks strive to treat such customers as retail products with a high degree of automation and standardized services.

At the other end of the spectrum, large corporations will have sufficient market power and financial strength (e.g. access to bond markets) to have multiple banks. Dealings will tend to be rather impersonal and driven mostly by price competitiveness. In between retail and large corporates are the "middle market" borrowers who can justify services from dedicated bank officers assigned to continuously deal with customers. This market segment has a high level of personal touch and fosters the bonds of an enduring business relationship. Moreover, as we will show, both parties find inherent advantages in building a relationship.

This is especially the case in the so-called "bank economies". In many continental European countries there are strong relationships between the CFOs or the representatives of the firms and the heads of the departments of the banks, e.g. the loan specialists (Pernsteiner and Węctawski, 2016). The latter system is called relationship banking. These relationships can be exclusive to one bank (strong relationship banking) or to two or even more banks (multiple or "split" banking). This term was defined in a relatively complex way by Ongena and Smith (2000), Boot (2000) and Berger and Udell (2002). As mentioned, it is a long and intensive partnership between banks and family firms that exceeds simple bundles of anonymous transactions. An advantage for banks is access to broader information about a firm. Firms that decided to tighten their relationships with banks are expecting easy access to financial support even if they have transitional economic troubles.

Boot (2000) defined relationship banking as a process of services rendered by banks that invest in access to specific information about the customer that is often not accessible for the public. The expected rate of return of this investment includes length of cooperation with a customer and a delivered portfolio of bank products. As Dong and Li (2010) pointed out, relationship banking can be described as formal cooperation among banks and companies. These relationships are stable over long periods of time, during which banks gather information related to businesses that is not 
accessible via formal sources and sometimes confidential. As noted, one of the most important characteristics is that these contacts exist over a long period of time, e.g. for more than a few years or even for decades. It must be clear that the bank(s) on the one side and the firms on the other side have expectations of some advantages and the opinion that these advantages are in total more important than the disadvantages, because otherwise the system would not sustain itself.

The literature (Section 2) describes the advantages and disadvantages for both partners. Based on numerous definitions, five dimensions of relationship banking were proposed: number of banks financing business entities, duration of relationship with banks, scope of relationships (services and products offered), part of credits delivered by dominant banks and possession of house bank status by the main bank (Presbitero and Zazzaro, 2010). In this paper we posit that relationship banking is synonymous with the number of banks with which the firm cooperates over a long time (as the independent variable, see Section 3).

Our purpose is to analyse the decision processes related to the number of bank relationships of the firms and determine why firms decide to have multiple bank relationships despite the obvious advantages of staying with one bank. The answers may help banks understand the thinking of firms and help the firms better decide how to arrange their relationships with a bank or banks.

Using an empirical methodology, we analyse data from a sample of actual Polish family firms. Our focus is thus on a large central European country with high growth rates after its transformation to a market economy in the early 1990s. We can say that this is a relatively short period for a market economy compared to traditional free markets elsewhere. The financial system is bank-oriented with a high participation rate by foreignowned banks, which represent more than 70 percent of total bank assets (Rozwój, 2016). The result is a high level of competition in the Polish banking sector. The next focus is on family firms, because they have a specific ownership structure that shows some distinctive characteristics. A distinctive attribute of family firms is their long-term perspective. Family firms tend to manage themselves for the next generation and hence are loath to put their permanence at risk by aggressive leverage. They also tend to put more emphasis on long-term business relationships, including those with their bankers (Chrisman et al., 2005). Therefore the family and its influence will be the central aspect in looking for a better understanding in relationship banking. 
As far as we know, this article is the first combining three of the most relevant aspects of relationship banking (number of banks; type of firms: family firms; actual country: Poland). This will be our contribution to the literature.

\section{LITERATURE REVIEW}

One of the most important drivers in the relationship between banks and firms is the asymmetrical information problem (Berger and Udell, 1995) and the fact that information is a key factor for banks to decide about their client's business activities, especially in the field of lending. Here we see relationship banking as especially important for mitigating the risks of lending. This mechanism is not new for banks. They have learned over a long time to reduce the inherent risks (von Rheinbaben and Ruckes, 2004; de la Torre et al., 2010) of opaque information and, along with collateral security and, most recently, covenants, have supplied a flow of credit. Information is lacking, especially in SMEs, for two reasons: their level for financial and management accounting skills is often not high, and their small size tends to prohibit audited financial statements, which tend to come with a fixed cost.

One of the most effective ways to capture important client information (Elyasiani and Goldberg, 2004; Elsas, 2005) is relationship banking. Here the bank gains access to both formal information (e.g. financial statements, tax returns, business plans) and informal or "soft" information (e.g. transaction history, community reputation, site visits, face-to-face interactions) that is more profound compared to transaction-oriented banking. Moreover, as experience is built up over continuous and repeated dealings, a bank witnesses a track record of behaviour that serves to build confidence. As the old saying goes, "to know them is to love them".

There are other attractions to relationship banking besides access to information. For the bank, there is the possibility to "cross sell" a range of banking products. The significance of relationship banking is that it is dependent on others' products and services rendered such as current accounts (Boot, 2000; Ongena and Smith, 2000). Moreover, the higher dependency and greater loyalty inherent in relationship banking allows high profit margins as a result of the (nearly) monopolistic status of the house bank ${ }^{1}$ (Degryse and Van

\footnotetext{
${ }^{1}$ By house bank, we mean the bank through which the company handles all payment transactions.
} 
Cayseele, 2000). Cultivating a strong relationship with a bank takes time. Indeed, there is often a stigma about switching banks. Over time, the house bank will also probably win more influence over strategic decisions because of the inter-personal relationships with business owners and managers (Pernsteiner and Węcławski, 2016). As a result of their relationship, it will be easier to sell future loans (Bharath et al., 2007) and other bank products such as personal loans, deposits, and insurance because of the bank's relationship with the owners (family) of the firm (Babcock, 2013). With the exception of the costs of such a relationship, there are no further disadvantages for the bank, but banks are cautious with family firms because they fear the misuse of the firms' assets (Steijvers and Voordeckers, 2009).

The general advantage for the firm as a whole in relationship banking lies in its function as "insurance" (Anderson et al., 2003, for founding family ownerships) in case of a deteriorated financial situation, when it is not easy or nearly impossible to get an additional loan. This is because the bank(s) in the relationship banking system will tend to give further loans as emergency liquidity (Sauter, 2015) when their loss is otherwise too high. Offsetting the disadvantage of the monopolistic behaviour of a house bank is the hope that the revenue concentration will make the firm a more valued customer (Degryse and Van Cayseele, 2000). Perhaps this will be more important for smaller banks and for a single (strong) or dual relationship banking (with two banks).

The second focus is on family firms. Without doubt, family firms, with their high numbers in continental European economies-even in the group of listed companies-are an important factor in the business field of these countries. Research into family firms has increased very rapidly, but not so intensively in the field of finance. Moreover, because of data availability, research into the financial problems of family firms is focused on listed companies. We concentrate here primarily on non-listed firms to contribute more to the literature. In the literature in general, and especially in empirical studies, we do not find an accepted definition of family firms (Felden and Hack, 2014). Very often the definition is determined by the availability of data, so in some studies, family firms are defined as a certain percentage of ownership by the family to show the influence of the family. At the other end of the spectrum there are "soft factors" that are part of the definition but are not so practicable for quantitative empirical research.

Generally, critical analysis allows stating that among the definitions presented in the literature, the first priority is given to a few specific core aspects in family businesses. They include ownership and possibility to 
control the company through ownership, the possibility of exerting a direct influence on decisions and management, conducting succession, the possibility to employ family members, the presence of persons from different generations, and the influence of family members not formally linked with the company on the way it operates (Barnes and Herson, 1976; Alcorn, 1982; Rosenblatt et al., 1985, Lyman, 1991; Gallo and Sveen, 1991; Donckels and Fröhlich, 1991; Beckhard and Dyer, 1983; Kepner, 1983; Goffee and Scase, 1985; Dyer and Handler, 1994). In this relatively vague situation, we decided to follow the definition of Klein (2010). Her concept is called Substantial Family Influence (SFI). The three categories are i) influence of the family in management; ii) influence of the family in controlling bodies; and iii) equity stakes. The three percentages must add up to over $100 \%$. In this model, the different influences of the family in the enterprise are shown to be very balanced and give a good impression of what a family firm is.

The main differences between family and non-family firms are independency and long-term orientation (Pernsteiner and Dick, 2013; Burgstaller and Wagner, 2015). The preference of independency means that family firms do not like banks to have too much influence (with loans), nor do they like external (e.g. outside the family) shareholders. The first aspect works against higher debt, the second one leads to lower equity. The empirical evidence is mixed. A family tends to think in terms of future generations. Therefore, they prefer a long-term orientation (Claver et al., 2009). To give the enterprise to the next generation, family firms tend to favour a risk-averse strategy, especially in investments (Dick et al., 2017).

The situation in the Anglo-Saxon world has been well researched (Astrachan et al., 2002). Because Poland is a large European country, research about it will bring added value. On the question of the number of bank relationships, there are cross-country differences (Ongena and Smith 2000). As a consequence, the research into the reasons for the differences in the number of bank relationships will be of considerable interest.

\section{DATA AND SAMPLE DESCRIPTION}

This empirical study is based on primary data collected within the Polish National Science Centre Project No. 2012/07/B/HS4/00455 "Corporate governance, ownership structure and other financial issues of family enterprises in Poland and Austria - a comparative analysis". The collection of original data was carried out in the second and third quarter of 2014 with 
the CATI and CAWI techniques. The survey agency made in total 12,155 phone calls to potential respondents who represented owners, CEOs and CFOs. As it turned out, 5,504 business entities declined to participate in the survey, and 4,235 withdrew during the investigation. Finally, 758 questionnaires were fully filled in. Hence, the total initial response rate for the collection of the purposive sample was only $6.2 \%$.

It should be mentioned that in detailed analyses the numbers of analysed companies differ due to lack of data (some companies did not fill out all the fields in the questionnaire), or the exclusion of bad data. The data contain a random sample of enterprises employing more than 49 persons; that means that "small firms" (i.e. less than 50 people employed) as defined by the EU are not included in the sample. The sample reflects the territorial structure of Poland and the size and sections (the Polish Classification of Economic Activities 2007) of the firms.

Using the Substantial Family Index (Klein, 2010), we identified 396 firms as "family firms", of which only a very small number is listed companies. Additionally, we confirm that the family firms in our sample have a high level of self-identification as family firms (319 firms, 80.6\%). In general, this is a sign that they are proud to be family firms. At this point another study could be mentioned in which the majority (86.3\%) of family businesses that perceive themselves as family firms are included in this group of companies on the basis of the SFI index (Zajkowski and Życzyński, 2014, pp. 236-247).

As mentioned, compared to other European countries, Poland is a transition market emerging from a centralized command economy with a relatively small private sector. The tradition of family firms is not as longestablished as in traditional free markets. More than 75 percent of the family firms in our sample were established between 1989 and 2003, the most dynamic period after the communist period. Therefore, more than two-thirds of the firms are controlled by the first generation. The average age of these family firms is 21 years. For details, see Table 1.

Table 1

Age of the firms and generation of the owners

\begin{tabular}{l|c|l|c}
\hline Period of foundation & $\begin{array}{c}\mathbf{n = 3 9 2} \\
\text { (in \%) }\end{array}$ & \multicolumn{1}{|c|}{$\begin{array}{c}\text { Generation } \\
\text { of the owners }\end{array}$} & $\begin{array}{c}\mathbf{n = 3 8 7} \\
\text { (in \%) }\end{array}$ \\
\hline Before 1989 & 14.0 & First generation & 68.0 \\
\hline $1989-2003$ & 75.5 & Second generation & 31.0 \\
\hline $2004-2014$ & 10.5 & Third generation and above & 1.0 \\
\hline
\end{tabular}

Source: own calculations. 
If we look into the sectors, size and turnovers, we can see a relatively clear structure. The main and dominant sector with 57 percent of the enterprises is manufacturing; the next sector is building and construction with nearly 14 percent. In the sample, the family firms in the strongest group (49\%) have 50-99 employees and are therefore medium-sized enterprises. At the other end of the spectrum, we find firms with 250 or more employees (6\%). Nearly 38 percent of the firms have a turnover in the range of PLN 5-19 million, while only 9 percent are over PLN 100 million.

Table 2

Sector, employment and turnover

\begin{tabular}{l|c|c|c|c|c}
\hline \multicolumn{1}{c|}{ Sector } & $\begin{array}{c}\mathbf{n = 3 9 6} \\
\text { (in \%) }\end{array}$ & Employees & $\begin{array}{c}\mathbf{n = 3 9 6} \\
\text { (in \%) }\end{array}$ & $\begin{array}{c}\text { Turnover in } \\
\text { PLN million }\end{array}$ & $\begin{array}{c}\mathbf{n = 3 7 1} \\
\text { (in \%) }\end{array}$ \\
\hline Manufacturing & 57.1 & $50-99$ & 49.2 & under 5 & 7.8 \\
\hline $\begin{array}{l}\text { Building and } \\
\text { construction }\end{array}$ & 13.8 & $100-149$ & 25.5 & $5-19$ & 37.8 \\
\hline Trade & 6.2 & $150-199$ & 10.9 & $20-49$ & 29.6 \\
\hline Service & 10.0 & $200-249$ & 8.6 & $50-100$ & 15.9 \\
\hline Others & 12.9 & 250 and more & 5.8 & more than 100 & 8.9 \\
\hline
\end{tabular}

Source: own calculations.

Another piece in the mosaic of the character of family firms is their goals. We asked if the following goals are very important, important, not so important or not interesting (it was possible to have multiple answers). More than $94 \%$ say that long-term orientation is very important. In all, $83 \%$ declare independence as very important, and nearly $78 \%$ choose risk reduction (this aligns with risk awareness). Long-term oriented value

Table 3

Goals of family firms

\begin{tabular}{l|c|c|c|c}
\hline \multirow{2}{*}{ Goals } & \multicolumn{4}{c}{ Relevance for family firms (in \%) } \\
\cline { 2 - 5 } & $\begin{array}{c}\text { very } \\
\text { important }\end{array}$ & important & $\begin{array}{c}\text { not so } \\
\text { important }\end{array}$ & $\begin{array}{c}\text { not } \\
\text { relevant }\end{array}$ \\
\hline Long orientation $(\mathrm{n}=394)$ & 94.1 & 3.1 & 0.8 & 2.0 \\
\hline Independency $(\mathrm{n}=395)$ & 83.0 & 8.9 & 4.0 & 4.1 \\
\hline Risk reduction $(\mathrm{n}=395)$ & 77.9 & 17.0 & 2.1 & 3.0 \\
\hline High growth rates $(\mathrm{n}=395)$ & 76.0 & 20.3 & 2.2 & 1.5 \\
\hline Long-term value improvement $(\mathrm{n}=396)$ & 73.0 & 18.7 & 4.5 & 3.8 \\
\hline High standard of living for the family $(\mathrm{n}=395)$ & 57.5 & 23.8 & 12.6 & 6.1 \\
\hline Short-term profit maximisation $(\mathrm{n}=394)$ & 43.4 & 28.2 & 24.3 & 4.1 \\
\hline
\end{tabular}

Source: own calculations. 
creation and high growth rates are important goals as well. Short-term profit maximisation is not so important compared to the other goals. This picture is consistent with the literature on family firms (Mishra and McConaughy, 1999).

The central focus of this article is the nature of relationship banking. We present the descriptive statistics about the number of banks with which firms have strong and long-lasting relationships. A dominant pattern is an exclusive relationship, but very close is cooperation with two banks. Three banks are seen as well, but more than that is rare. If we look at the duration of cooperation, we can see that the majority lie in the range of 6 to 15 years, as many as 18 percent are in the range of 16 to 20 years. Taken together this will make a consistent picture. For a detailed breakdown, see Table 4.

Table 4

Relationship banking

\begin{tabular}{c|c|c|c}
\hline $\begin{array}{c}\text { Number } \\
\text { of banks }\end{array}$ & $\begin{array}{c}\mathbf{n = 3 9 1} \\
\text { (in \%) }\end{array}$ & $\begin{array}{c}\text { Duration } \\
\text { of partnerships in years }\end{array}$ & $\begin{array}{c}\mathbf{n = 3 8 5} \\
\text { (in \%) }\end{array}$ \\
\hline 1 & 42.7 & 5 and less & 12.2 \\
\hline 2 & 39.4 & $6-10$ & 30.9 \\
\hline 3 & 13.3 & $11-15$ & 22.6 \\
\hline 4 & 2.6 & $16-20$ & 18.0 \\
\hline 5 and more & 2.0 & 21 and longer & 16.3 \\
\hline
\end{tabular}

Source: own calculations.

\section{MODEL AND HYPOTHESES}

As mentioned, our main topic is to identify how family firms decide to cooperate with a given number of banks and why they decide to use two or more banks in a relationship banking mode with a long and intensive cooperation between them. Specifically, we are looking for the factors that influence the firm's choice of the number of banks with which to have in a relationship.

Importantly, we do not analyse why a family firm starts cooperating with one bank because it is obvious in the Polish law system and it is necessary to operate in the market. This situation (cooperation with one bank) was for us the starting point to identify the reasons of cooperation initiation with two, three and more banks. Taking into consideration this approach, we elaborated the hypotheses below. 
The SFI classification gives an objective orientation as a family firm. In our interview-based questionnaire, we asked for the "feeling as a family firm", i.e. we would like to see the emotional influence. Family firms like a personally oriented long-term relationship and see relationship banking as insurance against possible future financial distress. Relationships imply loyalty and commitment, even in the face of adversity. "We are with you through good times and bad times". Therefore, a strong relationship is important, and they thus have a tendency to engage with a lower number of banks.

Hypothesis 1. Family firms, which see themselves as family firms, tend to have relationship banking with a smaller number of banks.

As mentioned, the share of family-owned equity is a very strong and important fact for the classification as a family firm and shows the strong influence of the family on the firm. According to the ideas in Hypothesis 1, we argue that a strong family influence will result in a lower number of banks in the bank relationship.

Hypotheses 2. Family firms with a high proportion of family-owned equity tend to have relationship banking with a smaller number of banks.

Families of such firms are often wealthy. Thus, they need expertise and management for their personal assets, primarily securities. They know some banks from their contacts with their firm's bank(s), and very often they turn to their company bank for their personal wealth management. At the same time, one of the main characteristics of the family firm is independency. Therefore, they do not want to put all their eggs in one basket.

Hypothesis 3. If the owners of family firms utilize one of the firm's relationship banks for their private wealth management, the firm will tend to have more banking relationships.

The main sector in our sample is manufacturing. Firms in this sector tend to have a strong technical focus. In general, we can say that service has not received a lot of attention in finance management. Thus, bank administration is not so important for them, and they tend to have a good partnership with one or only a small number of banks. Furthermore, manufacturing firms tend to be more capital-intensive (as regards production assets and inventory) compared to wholesalers, retailers and service firms. Capital intensity will tend to increase the need for access to financing sources, which in turn favours more exclusive banking relationships.

Hypothesis 4. Family firms in the manufacturing sector tend to cooperate with a smaller number of banks than family firms in other sectors. 
The size of an enterprise is an important factor for analysing relationships. Larger firms are more diversified and tend to have more international activities due to their broader variety of products and services. Consequently, they tend to have more bank relationships.

Hypothesis 5: Larger family firms tend to cooperate with more banks.

To test our hypotheses, we ran a multinomial logit model. This model describes a situation when the dependent variable is discretely selected from a set consisting of more than two categories.

In our case, the firm is cooperating with a certain number of banks, but the last situation is a group with an unlimited number of banks (five and more). The application of this model of disordered categories makes it possible to analyse the effects of each variable for each alternative for the number of banks; this would be not possible for ordered categories.

The procedure is realized in three steps. In the first step, we look for some attributes of family firms from our quantitative research such as the age of the firm, ownership generation and self-identification as a family firm. In the second step, we realize the estimation of some models for some variables and find the significance. In the third step, we use the criteria of Akaike, Schwarz and Hannan-Quinn, and find the best model for factors such as self-identification as a family firm, stake of family equity, private wealth management, sector and size of the firm.

The model is based on a cross-sectional data set. The dependent variable is the number of banks the firm has been cooperating with over a long time. The independent variables are determined by the hypotheses. The independent variables are self-identification of family firms (SELF) as family firm (1) and as non-family firm (0); the percentage of the familyowned equity of the equity of the family firm (EQ); the bank serves as the bank for the firm and for the family (BANK_PRIV) (1) and the bank does not serve for the family (0); the family firm is part of the manufacturing industry (PROD) (1) and is not in this sector (0); and factor size of family firms (SIZE) with (1) for medium-sized firms, 2 for large firms and 3 for very large firms. For all calculations the program GRETL (Gnu Regression Econometrics and Time-series Library) is used.

The model describes the result of a discrete selection of the number of banks with which the family firms have been cooperating over an extended period. The data interpretation of the results is based on the concept of stochastic utility. The firms select their banks in a rational way and look therefore for maximising the utility of their decisions. The collection of facts for finding a solution is limited, and it is uncertain if the decisions of the 
firms were the best ones. Therefore, the interpretation of the results must be based on the theory of stochastic utility. A positive number for one variable shows that the variable has an impact in increasing the probability of collaboration with more banks. The independent variables in this model have a lower level of estimated correlation for the Variance Inflation Factor (VIF) $(j)=1 /\left(1-(j)^{\wedge} 2\right)$, when $R(j)$ is the coefficient of the multiple correlation between the variable " $\mathrm{j}$ " and all the other independent variables of the model.

Model: Multinomial Logit, using observations 1-396 ( $\mathrm{n}=369$ )

Missing or incomplete observations dropped: 27

Dependent variable: BANK_STABLE 1-3

Standard errors based on Hessian

\begin{tabular}{l|r|r|r|r|c}
\hline & Coefficient & Std. Error & \multicolumn{1}{c|}{$Z$} & p-value & \\
\hline BANK_STABLE =2 & & & & & \\
\hline constant & 0.054 & 1.231 & 0.044 & 0.965 & \\
\hline SELF & -0.605 & 0.301 & -2.011 & 0.044 & $* *$ \\
\hline EQ & -0.012 & 0.010 & -1.220 & 0.223 & \\
\hline BANK_PRIV & 0.234 & 0.193 & 1.215 & 0.224 & \\
\hline PROD & 0.302 & 0.238 & 1.270 & 0.204 & \\
\hline SIZE & 0.869 & 0.610 & 1.425 & 0.154 & \\
\hline BANK_STABLE $=3$ & & & & & \\
or more banks & & & & & \\
\hline constant & -7.704 & 2.349 & -3.280 & 0.001 & $* * *$ \\
\hline SELF & 0.042 & 0.437 & 0.097 & 0.923 & \\
\hline EQ & 0.036 & 0.022 & 1.660 & 0.097 & $*$ \\
\hline BANK_PRIV & 0.773 & 0.257 & 3.013 & 0.003 & $* * *$ \\
\hline PROD & -0.660 & 0.314 & -2.102 & 0.036 & $* *$ \\
\hline SIZE & 1.892 & 0.631 & 2.999 & 0.003 & $* * *$ \\
\hline
\end{tabular}

Note: $* \mathrm{p}<0.1 ; * * \mathrm{p}<0.05 ; * * * \mathrm{p}<0.01$

Mean dependent variable

Log-likelihood

Schwarz criterion
1.762

$-364.521$

799.972
S.D. dependent variable Akaike criterion

Hannan-Quinn
0.735

753.042

771.685

Number of cases 'correctly predicted' $=170(46.1 \%)$

Likelihood ratio test: Chi-square $(10)=37.534$ [0.0000]

Variance Inflation Factors: Minimum possible value $=1.0$; values $>10.0$ may indicate a collinearity problem.

SELF 1.023; EQ 1.031; BANK_PRIV 1.005; PROD 1.014; SIZE 1.007

$\operatorname{VIF}(j)=1 /\left(1-R(j)^{\wedge} 2\right)$, where $\bar{R}(j)$ is the multiple correlation coefficient between variable $\mathrm{j}$ and the other independent variables. 


\section{RESULTS AND DISCUSSION}

Significant numbers of firms are open to cooperation with a second bank, but with a falling tendency (see the negative sign of the parameter) to cooperate with three or more banks. However, the benefits of more banks are subject to dilution. Relationships are inherently exclusive, otherwise they are not "relationships" with re-enforcing cycles of continuity, mutual benefits and trust. Hence, in the case of cooperation with three or more banks, we see very little preference. This means that we can accept Hypothesis 1 and say that this group of family firms is inclined to cooperate with a small number of banks.

These "strong and emotional" family firms are looking for a strong partnership in banking affairs and find them with two banks. This will give more stability and a better insurance function against bad financial situations. Maybe it is a sign of independence to have more than one bank, but not too many because they like stability and good interrelations. This finding conforms with Polish reality and the study by Gajewski et al. (2012), which confirms that the relationship with one bank is the dominant one for Polish firms (60\%), which is consistent with the results from our data presented in Table 3.

Just as Hypothesis 1 is more focused on "strong family firms", Hypothesis 2 is in fact more oriented to the share of the family in the firm's equity. There is a weak but insignificant relationship between a high share of a family in the firm's equity and a long period of cooperation with a small number of banks; this weak relationship is only some way from two to three banks. We cannot accept this hypothesis.

We can see here the difference between a more emotional view and a financial view in the last case. Therefore, we can recommend that banks should emphasise nurturing inter-personal ties between bank staff and owner/managers if they are interested in sustaining a strong banking relationship. An implication here is that banking officers should possess inter-personal skills and emotional intelligence, i.e. they should be "people persons" as well as possessing analytical credit analysis skills. Another implication is staff turnover. Relationship banking is difficult to sustain if bank officers come and go with too much frequency.

Hypothesis 3 can be accepted to explain why firms diversify to two to more banking relationships. If there is a relationship between the family and the bank(s) for their private wealth management, the family firm will tend to have more banks. Presumably the bank dealing with the family will leverage 
any goodwill to gain a foothold inside the firm. We also see that family firms value independence. This suggests wariness about being dependent on a single-banking relationship even if exclusivity offers inherent advantages.

For family firms in the manufacturing sector, we can confirm Hypothesis 4. They tend to have more exclusive banking relationships compared to the other sectors. We see this as a significant factor in the case of moving from two to three banks. As noted, since they are more technically oriented, service is not so important to them. They perceive bank services as being less valuable or undifferentiated ("all the banks are the same; why bother with more?"). Capital intensity and the need to finance it will also favour more exclusive banking relationships. Finally, maybe they are more oriented to Poland so they have no currency risk problems and they are not so sophisticated about financial issues.

We see the significant influence of the size of the family firm and the inclination to deal with more banks, especially the tendency to use three and more banks. Thus, Hypothesis 5 is accepted. The arguments (more diversified, more products and services and maybe more international activities) are confirmed.

To sum up, the default tendency for family firms that are highly dependent on a bank for access to credit is to have an exclusive, ongoing relationship with a primary or "house" bank. This suits the needs of both parties. This explains why the exclusive house bank business model is so common. However, in the case of a sample of medium-sized family firms, we see that a significant number has diversified their banking relationships. In view of the inherent advantages of a single house bank, we explore why firms might choose to deal with two or more banks. Thus through statistical analysis we identified several motives.

a) Self-identification as a family firm and a desire to shun dependency will tend to favour having a second banking relationship in the spirit of diversifying sources of supply and encouraging competition;

b) If the owners are utilizing separate banking services for their own wealth management (investments, savings) and personal credit (credit cards, car loans, mortgages), the firm will tend to have more business bankers, most probably because the private bank uses the relationship with owners to get an "in" to the firm's business;

c) Manufacturing family firms tend to have a lower number of banks than firms in other sectors. We might speculate as to the reasons why. One reason could be that the firms have a technical or engineering orientation that does not readily focus on financial issues. The benefits of diversified 
banking might be ignored. Otherwise the capital intensity of manufacturers (regarding production capacity and inventory stocks) might require greater access to bank credit, which in turn favours more exclusive banking relationships.

d) Not surprisingly, as family firms increase in size, they tend to expand the number of their banking relationships, possibly going to three or more banks. Many of these more mature firms will have accumulated greater levels of retained earnings and will have reduced or even eliminated bank debt. Their size also allows them to be better at financial reporting. The opacity problem is less of a constraint. All this serves to reduce the need for an exclusive house bank relationship.

There are some implications from these findings for banks. First, they should be prepared to share client relationships with other banks as family firms develop and grow. Second, the strength (in terms of durability, loyalty, tolerance) of banking relationships will likely reflect the inter-personal relationships between owner-managers and bank officers assigned to handle the relationship. There is a personal element in banking. Family firmoriented banks will want to ensure - through selection, training, empowerment, turnover - that bank staff have the capacity to form loyal inter-personal bonds with their clients.

As mentioned, we use data from Poland, and from this geographical point it is not possible to generalize for all of Europe. We use data from 2014, perhaps there was a difference in 2017 because the economy is recovering from the crisis period. The authors gratefully acknowledge the financial aid granted by the Polish National Science Centre (NCN Project No. 2012/07/ B/HS4/00455, "Corporate governance ownership structure and other financial issues of family business in Poland and Austria - a comparative analysis") to conduct this research.

\section{REFERENCES}

Alcorn, P., Success and survival in the family-owned firm. McGraw Hill, New York 1982.

Anderson, R. C., Mansi, S. A., Reeb, D. M., Founding family ownership and the agency cost of debt, "Journal of Financial Economics", 68, pp. 263-285, 2003.

Babcock, W. K., Family banks: Using corporate entities and trust, “Trust Estates”, pp. 40-43, 2013.

Barnes, L., Herson, S., Transforming power in the family business, "Harvard Business Review", December, pp. 377-392, 1994.

Beckhard, R., Dyer, W., Managing continuity in the family-owned business, "Organizational Dynamics", 12, pp. 5-12, 1983. 
Berger, A. N., Udell, G. F., Relationship lending and lines of credit in small firm finance, "Journal of Business", 68, pp. 350-381, 1995.

Berger, A. N., Udell, G. F., Small business credit availability and relationship lending: The importance of bank organizational structure, "Economic Journal", 112, F32-F53, 2002.

Bharath, S., Dahiya, S., Saunders, A., Srinivasan A., So what do I get? The bank's view of lending relationships, "Journal of Financial Economics", 85, pp. 368-419, 2007.

Boot, A. W., Relationship banking: What do we know?, "The Journal of Financial Intermediation", 9, pp. 7-25, 2000.

Burgstaller, J., Wagner, E., How do family ownership and founder management affect capital structure decisions and adjustment of SME?, "The Journal of Risk Finance”, 16, pp. 73101, 2015.

Claver, E., Rienda, L., Quer, D., Family firms' international commitment: The influence of family-related factors, "Family Business Review", 22, pp. 125-135, 2009.

Chrisman, J., Chua, J., Sharma, P., Trends and directions in the development of a strategic management theory of the family firm, "Entrepreneurship Theory and Practice", 29, pp. 555-576, 2005.

Degryse, H., Van Cayseele, P., Relationship lending within a bank-based system: Evidence from European small business data, "Journal of Financial Intermediation", 9, pp. 90-109, 2000.

Dick, M., Mitter, C., Feldbauer-Durstmüller, B., Pernsteiner, H., The impact of finance and governance on the internationalisation modes of family firms, "European Journal of International Management", 11, pp. 42-64, 2017.

Donckels, R., Fröhlich, E., Are family businesses really different? European experiences from Stratos, "Family Business Review", 4, p. 152, 1991.

Dong, B., Li, Y., The relationship banking paradox: No pain no gain versus raison d'être. Working Paper, School of International Trade and Economics, Beijing 2010.

Dyer, W. G., Handler, W., Entrepreneurship and family business: Exploring the connections. "Entrepreneurship Theory and Practice", 1, pp. 71-84, 1994.

Elsas, R., Empirical determinants of relationship lending, "Journal of Financial Intermediation", 14, pp. 32-57, 2005.

Elyasiani, E., Goldberg, L. G., Relationship lending: A survey of literature, "Journal of Economics and Business", 56, pp. 315-330, 2004.

Felden, B., Hack, A., Management von Familienunternehmen. Besonderheiten - Handlungsfelder - Instrumente [Management of Family Firms: Special features - Activity Fields - Tools]. Wiesbaden 2014.

Gajewski, K., Pawłowska, M., Rogowski, W., Relacje firm z bankami w Polsce $w$ świetle danych ze sprawozdawczości bankowej [Relationship banking in Poland in the light of banking reporting data]. „Materiały i Studia”, no. 275, NBP, Warszawa 2012.

Gallo, M. A., Sven, J., Internationalizing the family business: facilitating and restraining factors, "Family Business Review", 4, pp. 181-190, 1991.

Goffee, R., Scase, R., Proprietorial control in family firms: Some functions of 'quasi- organic' management systems, "Journal of Management Studies", 22, pp. 337-352, 1985. 
Kepner, E., The family and the firm: A co-evolutionary perspective, "Organizational Dynamics", 12, pp. 58-70, 1983.

Klein, S., Familienunternehmen. Theoretische und empirische Grundlagen [Family Firms. Theoretical and empirical Fundamentals], 3rd ed. Lohmar-Köln 2010.

Lyman, A. R., Customer service: Does family ownership make a difference?, "Family Business Review", 4, pp. 303-324, 1991.

Ongena, S., Smith, D. C., Bank relationships: A review [in:] Zenios, S., Harker, P. (eds.), Performance of financial institutions, pp.221-258. Cambridge University Press, Cambridge 2000.

Ongena, S., Smith, D. C., What determines the number of bank relationships? Cross-country evidence, "Journal of Financial Intermediation", 9, pp. 26-56, 2000.

Pernsteiner, H., Dick, M., The capital structure and the dividend policy of family firms, “Annales Universitatis Mariae Curie-Skłodowska”, Sectio H, 47, pp. 95-104, 2013.

Pernsteiner, H., Węcławski, J., How do Polish non-listed family firms engage in strong relationship banking? [in:] Asal, M. (ed.), Contemporary Problems in Corporate Governance, "Rapport Högskolan Väst", 3, pp. 45-57, 2016.

Presbitero, A. F., Zazzaro, A., Competition and relationship lending: friends or foes? Working Paper, 3103, CESifo, 2010.

v. Rheinbaben, H., Ruckes, M., The number and the closeness of bank relationships, "Journal of Banking and Finance", 28, pp. 1597-1615, 2004.

Rosenblatt, P. C., Mik, L., Anderson, R. M., Johnson, P. A., The family in business. JosseyBass, San Francisco, 1985.

Rozwój system finansowego w Polsce w 2016 r. [Financial system development in Poland in 2016]. NBP, Warsaw 2017.

Sauter, K., Die Hausbankenbeziehung aus Sicht von Familienunternehmen [Relationship Banking from the Point of View of Family Firms], "Bank und markt", pp. 28-31, 2015.

Steijvers, T., Voordeckers, W., Private family ownership and the agency costs of debt, "Family Business Review", 22, pp. 333-346, 2009.

de la Torre, A., Martinez Peria, M., Schmukler, S., Bank involvement with SMEs: Beyond relationship banking, "Journal of Banking and Finance", 34, pp. 2280-2293, 2010.

Tymoczko, I. D., Charakter wspólpracy przedsiębiorstwa z bankiem a warunki cenowe kredytu bankowego [The nature of business cooperation with the bank versus the pricing terms of bank lending], „Materiały i Studia”, 268, NBP, Warsaw 2012.

Zajkowski, R., Życzyński, N., Percepcja a rzeczywiste wyróżniki przedsiębiorstw rodzinnych [Perception and actual distinguishing features of family enterprises], "Ekonomia i Zarządzanie", 6, pp. 236-247, 2014.

Received: December 2017, revised: November 2018 